\title{
Clear cell ovarian cancer and endometriosis: is there a relationship?
}

\author{
Maria Szubert ${ }^{1,2}$, Jacek Suzin ${ }^{1,2}, K^{2}$ atarzyna Obirek ${ }^{3}$, Amanda Sochacka3 ${ }^{3}$ Marta Łoszakiewicz ${ }^{3}$ \\ ${ }^{1}$ Clinic of Operative and Oncologic Gynaecology, First Department of Gynaecology and Obstetrics, Medical University of Lodz, Poland \\ ${ }^{2}$ M. Pirogow's Teaching Hospital, Lodz, Poland \\ ${ }^{3}$ Students Scientific Society at the First Department of Gynaecology and Obstetrics, Medical University of Lodz, Lodz, Poland
}

\begin{abstract}
Introduction: Ovarian clear cell carcinoma is a rare type of ovarian cancer. In recent years, issues of the common genetic origin of endometriosis and ovarian clear cell carcinoma have been raised.

Aim of this study was to evaluate the prevalence of this type of cancer, risk factors, prognosis and its potential aetiological association with endometriosis.

Material and methods: In a retrospective study, we analysed histopathological data of patients operated in the First Department of Gynaecology and Obstetrics (MU, Lodz) due to ovarian cancer in 2004-2014. Among the 394 patients operated on for ovarian cancer, clear cell carcinoma was found in 0.02\% (9/394). Menstrual history, parity, comorbidities, data from physical examination, operational protocols and histopathological diagnoses were analysed. Follow-up was obtained from $77.8 \%$ of patients. Statistical analysis was performed using Microsoft Excel 2013.

Results: The mean age of patients at diagnosis was 57.6 years; the BMI in the study group was 27.2; the majority of patients were multiparous $(77.8 \%)$. Clear cell carcinoma was detected mostly at stage la $(n=4)$. The concentration of Ca125 in the study group had an average of $142.75 \mathrm{U} / \mathrm{ml}$ and a median of $69.3 \mathrm{U} / \mathrm{ml}$. The coexistence of endometriosis could not be clinically or histologically confirmed amongst our patients. The most common comorbidity in the study group was hypertension.

Conclusions: In our clinical material, ovarian clear cell carcinoma is a rare histopathological specimen with a prognostic value comparable to that of serous ovarian cancer. Due to the rarity of this histopathological subtype, proving a cause-and-effect relationship between it and endometriosis can only be elucidated through statistical studies of the entire population.
\end{abstract}

Key words: histological subtypes of ovarian cancer, FIGO, rASRM, endometrial lesions.

\section{Introduction}

Ovarian cancer is a malignant neoplasm derived from epithelial cells of the ovary. In the world data on ovarian cancer in 2012, it was reported to have a morbidity and mortality of 239,000 and 152,000 , respectively [1]. In Poland it is the sixth most common malignant tumour in women (the number of cases in 2010 amounted to almost 3,600) and the fourth most frequent cause of cancer deaths (over 2,500 deaths in 2010) [2, 3]. Until recently, ovarian clear cell carcinoma stood out through its unique structure (morphology) and unfavourable prognosis, and above all resistance to chemotherapy [4]. Recent years have found some of the specific molecular characteristics of ovarian clear cell carcinoma, such as PI3CA mutation (kinase domain of phosphatidylinositol 3 kinase), ARID1a mutation (AT rich interactive domain $1 \mathrm{~A}$ ) and $\mathrm{MET}$ amplification (oncogene receptor tyrosine kinase) [4]. Furthermore, the aim of the study was to establish a relationship be- tween endometriosis and this type of cancer. We have undertaken an attempt to assess whether the relationship between endometriosis and ovarian clear cell carcinoma is coincidental or whether there is a cause-andeffect relationship between these two disease entities. The study is relevant because of the fact that there has been a significant increase in the number of patients with endometriosis in the world, which even in our clinic constitutes a significant proportion of patients diagnosed for pelvic pain (approximately 67\%) [5].

The risk of developing ovarian cancer increases in nulliparous women with a family history of ovarian or breast cancer, as well as in those with early menarche. The risk of ovarian cancer is reduced with infrequent ovulatory cycles as is the case for women who have given birth or are taking hormonal contraceptives $[2,6]$. The same factors also affect the occurrence of endometriosis. Endometriosis itself is considered a risk factor for ovarian cancer. This relationship attracted attention back in the days of Sampson's research on the disease in the 
1930s. According to the most recent systematic review of the literature, the risk is small and is $1.321 .7 / / 1.3217$ $(95 \% \mathrm{Cl})$ [7]. There are many publications on the relationship of endometriosis with ovarian clear cell carcinoma, however, it is not known whether these two diseases have a common aetiology and whether the relationship is sequential in nature, i.e. endometriosis developing into cancer through malignant transformation [8].

The aim of this study was to investigate the relationship of clear cell carcinoma with endometriosis and analysis of possible common risk factors for both of these disease entities in respect of data from available literature. The study was based on data collected in a retrospective analysis of clinical material from 2004-2014.

\section{Material and methods}

In a retrospective study done by the Department of Operative and Oncological Gynaecology at the Medical University of Lodz, histopathological data of ovarian cancer from 2004-2014 were analysed. The search terms in PubMed and Web of Science were the words or phrase "clear cell carcinoma, ovarian cancer, clear cell, sophisticated histopathological findings but dealt with an organ other than the ovary". Of the 394 ovarian cancers found, 9 had dealt with histopathology. These 9 papers formed the basis of our patient selection, and we then analysed their data on menstrual history, diversity, comorbidities, data from the physical examination and operational protocols and histopathological diagnosis. Prospective data from follow-up were obtained from 7 patients. Each patient gave her consent to anonymously publish her data. Statistical analysis was performed using Microsoft Excel 2013.

\section{Results}

Among the 394 patients operated for ovarian cancer in our clinic in 2004-2014, the patients with ovarian clear cell carcinoma (OCCC) type accounted for $0.02 \%$

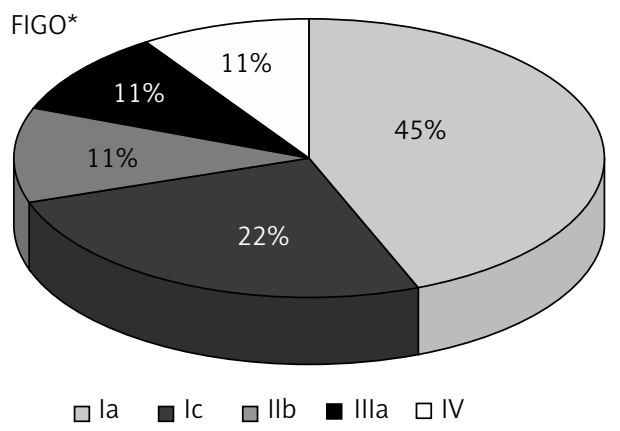

* International Federation of Gynecology and Obstetrics staging classification for cancer of the ovary

Fig. 1. The prevalence of each stage of ovarian cancer in the studied group of patients with clear cell cancer
(9/394). In our study group of OCCC, the mean age at diagnosis was 57.6 years and a mean BMI of $27.2 \mathrm{~kg} / \mathrm{m}^{2}$. The study showed that $77.8 \%$ of respondents have gone through pregnancy $(n=7)$ and that most of the patients were multiparous (85.7\%) $66.7 \%$ of all analysed patients. OCCC was detected mostly in the stage la $(n=4)$ (Fig. 1). The concentration of Ca125 in the study group averaged $142.75 \mathrm{U} / \mathrm{ml}$; median $69.3 \mathrm{U} / \mathrm{ml}$ (Table I). None of the patients had clinically or histologically confirmed coexistence of endometriosis. The most common morbidities in the study group were hypertension and obesity affecting 33\% of patients in both cases, and thrombocythemia which was seen in $22 \%$ of patients. Follow-up was achieved in $77.8 \%$ of patients $(n=7), 42.8 \%$ of which remained in remission $(n=3)$ after radical treatment operations and first-line chemotherapy (Table II). One patient managed to stabilize her disease but suffered from progression after a year, subsequently being placed on second-line chemotherapy. In another patient, upon completion of firstline treatment, remission was achieved for a year until relapse of a vaginal tumour, which was then treated with brachytherapy. Death from cancer was confirmed in one patient who was operated on with stage la ovarian cancer. This patient suffered a recurrence of her cancer one year from diagnosis which led to her death.

\section{Discussion}

In recent years, the world has observed an increase in incidence of ovarian cancer. Peak incidence coincides with the postmenopausal period with the age of 4070 years [2]. This age distribution is also present in our study group. Ovarian cancers due to their histopathological structures are divided into: serous, mucinous, endometrioid, clear cell, mixed and undifferentiated carcinoma (source: WHO; http://webcache.googleusercontent.com/search?q=cache:sxun1BsGqPMJ:https:// www.seap.es/documents/228448/528821/01_Prat. $p d f+\& c d=1 \& h l=p l \& c t=c \mid n k \& g l=p l)$. The OCCC repre-

Tab. I. Values of Ca-125 (Cancer antigen 125) in the studied group

\begin{tabular}{ccc}
\hline & FIGO* $^{*}$ & Ca125 [U/ml] \\
\hline 1 & la & 4.2 \\
\hline 2 & la & 7.1 \\
\hline 3 & la & 205 \\
\hline 4 & Ic & 25.8 \\
\hline 5 & Ic & 69.3 \\
\hline 6 & Ilb & 106.5 \\
\hline 7 & IIla & 124.1 \\
\hline 8 & IV & $>600$ \\
\hline 9 & IV & Lack of data \\
\hline
\end{tabular}


sents a small percentage of ovarian cancers (approx. $112 \% / / 11.2 \%$ ) $[9,10]$. In our study, of 394 patients operated within a 10 -year period, pathologists recognized OCCC in < $1 \%$ of patients with ovarian cancer. Only the Japanese population, wherein the ovarian cancer is less common than in the other populations, is characterized by a greater proportion of OCCC of $15-25 \%$ [11]. The prognosis of this tumour type is described as worse than those of other histological subtypes with a 5-year survival of around 30\% [12-14]. One of the reasons for the poor prognosis is the late diagnosis of the disease. Therefore, the determination of the genetic relationship between endometriosis and OCCC could be helpful to patients with endometriosis by closely monitoring them as well as the possibility of applying preventative measures [15]. This cancer is difficult to be detected and even small primary lesions may result in distant metastasis. It spreads contiguously in the peritoneal cavity and through lymph vessels, as opposed to the more common route of blood vessels [2]. In the early stages of OCCC, the symptoms are nonspecific and become more noticeable with the progression of the disease [15]. These include, among others: abdominal distension, pelvic pain, ascites, and dysuria [15-17]. Chronic and especially severe endometriosis may also have this characteristic pelvic pain making it a part of our differential diagnosis [18]. The differential diagnosis of cancer takes into account: physical examination, imaging investigations: transvaginal and transabdominal ultrasound, CT, MRI, concentration of Ca125, and the risk calculated in the algorithms RMI and ROMA (called risk of malignancy index; risk of ovarian malignancy algorithm) (http://xemamedica.com/eng/calc/) $[2,19]$. Definitive diagnosis is made based on the histological examination of stretch material taken during surgery. The treatment of choice is radical surgery with inter- or post-operative cytoreduction by chemotherapy. Clear cell carcinomas are biologically aggressive cancers and mostly resistant to conventional platinumbased chemotherapy. However, the early stages of clear cell cancer have a good prognosis and may not require adjuvant therapy [20]. Thrombosis occurs more often in patients with OCCC as demonstrated in our study group with a thrombocythemia occurring in $22 \%$ of patients, although no serious thrombotic complication were observed.

Studies on the transformation of endometrial lesions into malignant neoplasm indicate that oncogenesis occurs most often in foci located in the ovaries. This transformation can be described as loss of heterozygosity, tumour suppressor genes p53 mutation and PTEN [21]. It seems that the progression from the benign lesion of endometriosis to invasive tumours, through the atypia and metaplasia and to the frank borderline tumours takes several years and is due to the accumulation of genetic changes [21]. Yamamoto et al. proved that mutations of the PIK3CA gene (phosphatidylinositol3kinase) may be one of the first events that initiate the transformation of endometriosis into OCCC [22]. This mutation was detected in approximately $33 \%$ of OCCC [23]. An interesting fact is that another mutation characteristic of endometriosis, endometriosis carcinoma, as well as of clear cell carcinoma is a tumour suppressor gene mutation ARID1A (AT rich interactive domain containing protein $1 \mathrm{~A}$ ) [4]. This gene regulates transcription of p53dependent proteins. It has been shown that mutations in this gene promote the development of carcinogenesis in mice. The presence of this mutation in both endometriosis and in OCCC may suggest a cause-and-effect relationship of these two diseases [24].

Tumours originating from endometriosis have some common features: they are most common in younger patients as compared to patients with squamous cell carcinoma of the ovary, they are detected in the lower stages with a higher degree of differentiation, and thus have a better prognosis [24]. Although we failed to find a relationship between OCCC and endometriosis in the study group, we drew attention to the fact that they have a better prognosis $-42.8 \%$ of patients with a 5 -year survival after diagnosis. According to the statistical data, the survival of patients with epithelial ovarian can-

Tab. II. Follow-up after initial diagnosis of clear cell ovarian cancer

\begin{tabular}{ccccc}
\hline Patient & Date of diagnosis & Treatment & Observation & Adjuvant therapy \\
\hline 1 & 17.10 .2007 & radical operation & remission & chemotherapy \\
\hline 2 & 28.06 .2011 & operation (non-radical) & progression in the abdomen & chemotherapy \\
\hline 3 & 22.08 .2011 & radical operation & lost to follow-up (FU) & - \\
\hline 4 & 21.05 .2012 & radical operation & remission & chemotherapy \\
\hline 5 & 02.07 .2010 & radical operation & $\begin{array}{c}\text { neoplastic infiltration of the urinary bladder suspected } \\
\text { - chemotherapy; metastasis in vagina - operation }\end{array}$ & $\begin{array}{c}\text { chemotherapy + } \\
\text { brachytherapy }\end{array}$ \\
\hline 6 & 10.11 .2010 & radical operation & alive & chemotherapy \\
\hline 7 & 07.12 .2011 & radical operation & remission & chemotherapy \\
\hline 8 & 15.06 .2012 & radical operation & death 16 months after diagnosis & radiotherapy \\
\hline 9 & 04.11 .2004 & operation - not radical & lost to FU & \\
\hline
\end{tabular}


cer is 46\% (source: http://www.cancerresearchuk.org/ cancerinfo/cancerstats/types/ovary/survival/ovariancancersurvivalstatistics). Zafrakas et al. reviewed the literature concerning the association between endometriosis and ovarian cancer. On the basis of the collected literature, they were unable to perform a meta-analysis. Their search yielded only one prospective cohort study, some case control studies and most of them were retrospective cohort ones [25]. The main limitation of most publications was the lack of operative confirmation of endometriosis. The risk of ovarian cancer in patients with endometriosis, in most of the retrospective studies, was determined at OR 3.05-3.41, which indicates a slight increase in risk, including OCCC - OR 3.05-3.41 [26-28]. However, a prospective study of Olson et al., which analysed 1392 patients with reported endometriosis in 13 years of observation has not found any association between endometriosis and ovarian cancer including OCCC (RR 0.8, 95\% Cl: 0.2-2.4) [29]. Zafrakas et al. conclude that the link of endometriosis and OCCC is still debatable on the basis of the above analysis of the literature [25]. The new discoveries of common genetic basis of endometriosis and OCCC have not been yet translated into the clinic and oncologic screening among patients with endometriosis.

\section{Conclusions}

In our clinical material, OCCC is a rare histopathological specimen with prognosis comparable to that of serous ovarian cancer. Establishing the cause-and-effect relationship between this histopathological subtype and endometriosis cannot be proved based on clinical material of only one clinic or operative ward. This issue requires statistical studies of available publications targeted at comparing the clinical and molecular groups of patients with endometriosis and OCCC.

\section{Acknowledgements}

The authors declare that the research was conducted in the absence of any commercial or financial relationships that could be construed as a potential conflict of interest.

\section{Disclosure}

Authors report no conflict of interest.

\section{References}

1. World Cancer Report 2014. Steward BW, Wild CP (eds.). $1^{\text {st }}$ ed. International Agency for Research on Cancer, World Health Organization 2014.

2. Stempczyńska J, Potemski P, Wójcik-Krowiranda K, Bieńkiewicz A. Nowotwory jajnika. In: Onkologia. Podręcznik dla studentów i lekarzy. Kordek R,
Jassem J, Jeziorski A, et al. (eds.). $4^{\text {th }}$ ed. Gdańsk, Via Medica; 2013: 238-242. 3. Wojciechowska U, Didkowska J, Zatoński W. Nowotwory złośliwe w Polsce w 2012 roku, Cancer in Poland in 2012. Ministerstwo Zdrowia, Warszawa 2014.

4. Yamashita Y. Ovarian cancer: new developments in clear cell carcinoma and hopes for target therapy. Jpn J Clin Oncol 2015; 45: 405-407.

5. Kowalczyk Amico K, Szubert M, Wierzbowski T, et al. Znaczenie laparoskopii w diagnostyce niepłodności w materiale Kliniki Ginekologii Operacyjnej i Onkologicznej Uniwersytetu Medycznego w Łodzi. Prz Menopauzalny 2010; 2: 105-108.

6. Chambers SK, Hess LM. Ovarian Cancer Prevention. In: Fundamentals of Cancer Prevention. Alberts D, Hess LM (eds.). $3^{\text {rd }}$ ed. Springer-Verlag, Berlin Heidelberg 2014: 557-591.

7. Dobrosz Z, Paleń P, Stojko R, et al. Clear cell carcinoma derived from an endometriosis focus in a scar after a caesarean section - a case report and literature review. Ginekol Pol 2014; 85: 792-795.

8. Myszewska A, Dudziak M, Kadylak B, Sznurkowski JJ. Rak jasnokomórkowy jajnika na podłożu zaawansowanej endometriozy pomenopauzalnej - opis przypadku i przegląd piśmiennictwa. Curr Gynecol Oncol 2013; 11: 82-88.

9. Köbel M, Kalloger SE, Huntsman DG, et al. Differences in tumor type in low-stage versus high-stage ovarian carcinomas. Int J Gynecol Pathol 2010; 29: 203-211.

10. Mackay HJ, Brady MF, Oza AM, et al. Prognostic relevance of uncommon ovarian histology in women with stage III/IV epithelial ovarian cancer. Int J Gynecol Cancer 2010; 20: 945-952.

11. Sugiyama T, Kamura T, Kigawa J, et al. Clinical characteristics of clear cell carcinoma of the ovary: a distinct histologic type with poor prognosis and resistance to platinum-based chemotherapy. Cancer 2000; 88: 2584-2589.

12. Spaczyński M. Onkologia ginekologiczna. $1^{\text {st }}$ ed. Elsevier Urban \& Partner, Wrocław 1997.

13. Chan JK, Teoh D, Hu JM, et al. Do clear cell ovarian carcinomas have poorer prognosis compared to other epithelial cell types? A study of 1411 clear cell ovarian cancers. Gynecol Oncol 2008; 109: 370-376.

14. Young RC, Walton LA, Ellenberg SS, et al. Adjuvant therapy in stage I and stage II epithelial ovarian cancer. Results of two prospective randomized trials. N Engl J Med 1990; 322: 1021-1027.

15. Goff BA, Mandel L, Muntz HG, Melancon CH. Ovarian carcinoma dignosis. Cancer 2000; 89: 2068-2075.

16. Goff BA. Ovarian Cancer: Symptoms and Presentation. In: Lichtman SM, Audisio RA (eds.). Management of Gynecological Cancers in Older Women. $1^{\text {st }}$ ed. Springer-Verlag, London 2013; 139-149.

17. Seiden MV. Gynecologic Malignancies. In: Harrison's Principles of Internal Medicine. Longo D, Fauci A, Kasper D, et al. (eds.). $18^{\text {th }}$ ed. McGrawHill Professional 2011.

18. Szubert M, Suzin J, Duechler M, et al. Evaluation of selected angiogenic and inflammatory markers in endometriosis before and after danazol treatment. Reprod Fertil Dev 2014; 26: 414-420.

19. Goff BA. Ovarian cancer: screening and early detection. Obstet Gynecol Clin North Am 2012; 39: 183-194.

20. Li X, Ye Z.; Clear cell carcinoma of the ovary: multi-slice computed tomography findings. World J Surg Oncol 2015; 13: 133.

21. Szubert M, Suzin J, Kowalczyk-Amico K; Konsekwencje endometriozy w menopauzie. Prz Menopauzalny 2012; 2: 142-145.

22. Yamamoto S, Tsuda H, Takano M, et al. PIK3CA mutation is an early event in the development of endometriosis-associated ovarian clear cell adenocarcinoma. J Pathol 2011; 225: 189-194.

23. Kuo KT, Mao TL, Jones S, et al. Frequent activating mutations of PIK3CA in ovarian clear cell carcinoma. Am J Pathol 2009; 174: 1597-1601.

24. Jones S, Wang TL, Shih le M, et al. Frequent mutations of chromatin remodeling gene ARID1A in ovarian clear cell carcinoma. Science 2010; 330: 228-231.

25. Zafrakas M, Grimbizis G, Timologou A, Tarlatzis BC. Endometriosis and ovarian cancer risk: a systematic review of epidemiological studies. Front Surg 2014; 8: 14.

26. Pearce CL, Templeman C, Rossing MA, et al. Association between endometriosis and risk of histological subtypes of ovarian cancer: a pooled analysis of case-control studies. Lancet Oncol 2012; 13: 385-394. 
27. Ness RB, Cramer DW, Goodman MT, et al. Infertility, fertility drugs, and ovarian cancer: a pooled analysis of case-control studies. Am J Epidemiol 2002; 155: 217-224.

28. Borgfeldt C, Andolf E. Cancer risk after hospital discharge diagnosis of benign ovarian cysts and endometriosis. Acta Obstet Gynecol Scand 2004; 83: 395-400.

29. Olson JE, Cerhan JR, Janney CA, et al. Postmenopausal cancer risk after self-reported endometriosis diagnosis in the lowa Women's Health Study. Cancer 2002; 94: 1612-1618. 